\title{
Development of Visual Block Programming Software for Supporting the Basic Programming Class in Vocational High School
}

\author{
Rustam Asnawi, I Gede Dangin Bagus Komang Surya Nuarsa \\ Electrical Engineering Education Department, Engineering Faculty \\ Yogyakarta State University \\ Yogyakarta, Indonesia \\ rustam@uny.ac.id
}

\begin{abstract}
This study aims to design and develop the learning media of visual block programming, and to know the level of eligibility of instructional media for the Basic Programming subjects in vocational high school. The research approached to Research and Development ( $R \& D)$. The overall stages in this research as follows: requirement analysis, product design, product development (including coding), product testing and feasibility tests. The results showed that visual block programming as learning media was working in accordance with the expectation. This was indicated by each sensor module that can detect the change of the given stimulus (the output is displayed in the monitor screen). The results of feasibility test by course material and instructional media experts got score $79 \%$ that was in "Eligible" category, and $80 \%$ that was included in the category of "Eligible". The result of feasibility test obtained from the users (students in vocational high school) was included in "Very Eligible" category, which was valid to be used as a learning media.
\end{abstract}

Keywords_- programming, visual block, learning media

\section{INTRODUCTION}

Scratch is a free programming language and support online community in which users can create interactive stories, animations, games, music, artwork, and application easily. Scratch helps and encourages young people (even children) to learn and to think creatively, systematically, and work together. It is a MIT Media Lab project from the Massachusetts Institute of Technology. For people who are just learning the computer programming, Scratch is a software application that is very easy to learn. Scratch programming uses some graphic symbols without syntax, it is usually called as Visual Block Programming. Visual Block programming is to create applications without any code [1]. Users will see, use, arrange and drag-drop "block" which are the command symbols and certain event handler functions to create an application. Users can simply develop an application without writing any program codes (coding less). The concept of Scratch is principally just composing the command blocks visually. Students can program by arranging blocks containing commands (called as "blocks") such as moving, speaking, or interacting when a key on keyboard is pressed. Scratch is primarily for children aged 8-16 years, means it can be used for kindergarten, elementary, up to high school students.
Visual block programming in Scratch is a programming language designed to introduce simple computer programming concepts for beginners. The beginners can learn and create programs without having to know and memorizing much syntax. The great feature (very simple and easy-to-use interface programming) makes the Scratch understandable to anyone from multiple backgrounds. The main idea of this programming model is visualizing the command and syntax in the form of blocks like in a puzzle game. In addition, visual block programming also allows users to understand the logical of mathematics and computer programming. Thus, the programming computer can be understood easily and fun with an attractive appearance.

On the other hand, Basic Programming is one of the compulsory subjects that must be taken by students in vocational high school especially for students of the Mechatronics Engineering Program. Basic competency that must be mastered first is to understand the programming algorithm as a basis for studying and understanding the next basic competence. Problem arises when students do not yet have a basic knowledge of programming algorithms. In addition students also have to memorize much different syntax on each programming language that was learned. The learning process commonly still uses conventional software such as Turbo C++ or Visual Studio [2] in which the interface of the IDE is still dominated by text. Then the simulation is done using a static learning media so that the teaching learning process becomes monotonic, students get bored quickly. Furthermore, when the program has been executed, students cannot see how the program is executed line by line, because the learning media does not have a real time monitor. As a result, the achievement of students' competence is less than optimal and does not meet the expected target.

Based on the above problems, it is necessary to develop a visual block Programming instructional media that can help teachers in the delivery of basic programming materials so the class becomes more interesting, easily understood materials and can improve student learning motivation [3]. Furthermore, this learning media should also be able to provide an overview the usage of sensors, actuators and how to develop computer programming easier. Therefore, the learning media designed was in the form of robot (similar to line follower robot) with monitor and control features for some portable sensor modules and actuators. In general, this learning media consists of 3 main 
parts: (1) the software for visual block programming, (2) the hardware that is a robot module and (3) the lab sheet modules. The software in part-1 is an application similar to IDE programming but it is specifically designed for visual block programming. It is mainly used for programming the controller of the hardware parts (the robot). The robot can move according to the program that has been created and can display the execution of program step-by-step on the screen monitor in real time.

Furthermore, to realize and implementing such learning media use a mini computer. Mini computers become very useful because it's portable and multifunction facilities. It makes widely used in the development of various innovative technologies. One type of minicomputer that is already known today is Raspberry Pi. Raspberry Pi is a mini computer device that its size is same as a credit card [4]. Raspberry pi has a Broadcom BCM2835 chip (SoC) system, which includes the ARM1176JZF-S $700 \mathrm{MHz}$ processor. Raspberry pi is able to support multiple operating systems optimized for it. One of the most popular is Raspbian which is the Debian version for Raspberry pi.

\section{METHOD}

The method used in this research was Research and Development (R \& D) which approached to and adopted from [5]. This research aimed to design, develop and test the feasibility of a learning media for basic programming in vocational high school that was visual block programming. The steps in the study as follows: needs analysis, product design, product development (including Coding), product testing and product feasibility tests.

\section{RESUlt AND Discussion}

The main component (processor) that was employed in this product was Raspberry Pi. It featured with a display monitor that helped users during programming and setting-up the sensors and actuators. Raspberry $\mathrm{Pi}$ had an USB port for creating connection with the Arduino UNO. The Arduino UNO was one of microcontroller system [6][7][8] that employed as an input output (IO) module in this research.

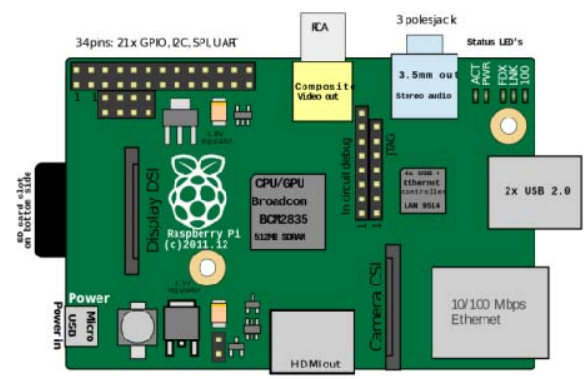

Fig. 1. Raspberry pi Module

The motor driver module had inputs that could be controlled by the IO module. IO module used a digital signal to adjust the direction and movement of the motor, and the PWM signal to adjust the speed of motor rotation. The line sensor module used a $3 \mathrm{~mm}$ LED as a light transmitter and a $3 \mathrm{~mm}$ photodiode as a light sensor receiver. The analog output of photodiode was 0 up to 5 volts converted into digital data by IC op-amp. The output would be sent to the IO module. Potentiometer was used to adjust the sensitivity of the sensor. The distance between the sensors was $1 \mathrm{~cm}$ conforming to the standard distance of the line follower robot. The type of proximity sensor module was used the HC-SR04. It had a measurable distance from $2 \mathrm{~cm}$ up to 5 meters with a resolution of $0.3 \mathrm{~cm}$, and the voltage consumption of 5 volts and current less than $2 \mathrm{~mA}$.

The main body was designed to resemble a line follower robot with wheels and a head. The body was made by acrylic material for easy disassembly by user, and also the user easier watched components inside the robot.

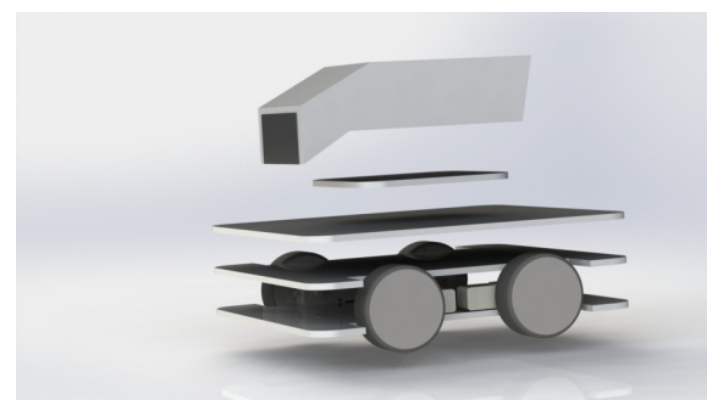

Fig. 2. The design of the main body

The design of the main body was made as attractive as possible to grab the user's attention and simplify the simulation of the program that had been created. The microcontroller modules were installed on the inside of the module to protect from collision and any external physic problems. Cable (jumper) installation was also made as simple as possible to make it easier for users to operate such learning media product.

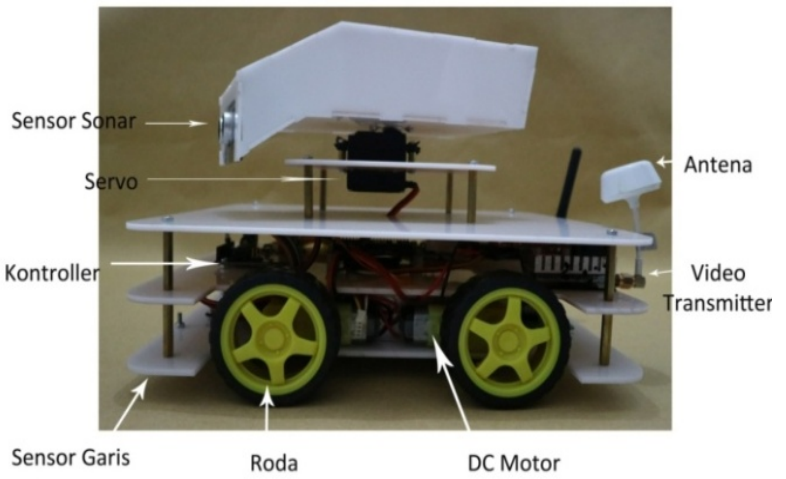

Fig. 3. The robot as learning media

The Arduino coding was created on Arduino IDE software run on a Windows PC [8]. The coding built algorithm which 
was able to translate the visual block program (that had been made on Raspberry Pi) into Arduino's codes. The Arduino's codes could operate (control) the motor, servo and reading sensors. Meanwhile the Raspberry's codes was made to connect the Arduino's program with the visual block programming. The program is created directly on the Raspberry Pi module in order to the visual block program could be directly applied to the robot device. This codes was made in Phyton and written directly on the Raspberry Pi.

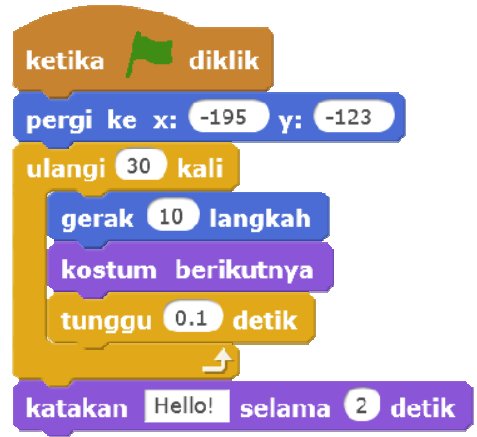

Fig. 4. The visual block program of Raspberry Pi

The feasibility tests by some experts were done to get the statement of validation that the product of learning media was suitable to be utilized in class [9]. The overall feasibility tests included the course material feasibility test obtained from two course material experts and the instructional media feasibility test obtained from two instructional media experts. A course material expert was someone who had expertise in the field of microcontroller or computer programming field, and an instructional media expert was someone who were experts in the field of learning media. The results are presented in Table I.

TABLE I. THE RESULTS OF VALIDATION TEST BY THE COURSE MATERIAL EXPERTS

\begin{tabular}{|l|c|c|c|c|}
\hline \multirow{2}{*}{ Validator } & \multicolumn{3}{|c|}{ Aspects of Assessment } & \multirow{2}{*}{ Category } \\
\cline { 2 - 5 } & $\begin{array}{c}\text { Course } \\
\text { material }\end{array}$ & Benefits & Total & \\
\hline $\begin{array}{l}\text { Material } \\
\text { expert 1 }\end{array}$ & 49 & 11 & 60 & Eligible \\
\hline $\begin{array}{l}\text { Material } \\
\text { expert 2 }\end{array}$ & 51 & 9 & 60 & Eligible \\
\hline Average & 50 & 10 & 60 & \\
\hline Category & Eligible & Very Eligible & Eligible & \\
\hline Percentage & $78 \%$ & $83 \%$ & $79 \%$ & \\
\hline
\end{tabular}

The course material aspect got $78 \%$ and on the benefit aspect got $83 \%$. Those data are obtained from 2 course material experts i.e. a lecturer who had expertise in microcontroller programming and a teacher who taught the basic programming subjects. The total result of the feasibility test by two course material experts got $79 \%$ which was included in the category of "Eligible". Regarding the total value obtained from both course material experts, the learning media was categorized as "Eligible" to be used as a learning media of basic programming subjects in vocational high school.

The instructional media feasibility test was conducted to determine the feasibility of such learning media of the visual block programming for supporting the basic programming subjects from the view of an instructional media expert [9]. This validation tests involved two instructional media experts. The results are presented in Table 2 .

TABLE II. THE RESULTS OF VALIDATION TEST BY THE INSTRUCTIONAL MEDIA EXPERTS

\begin{tabular}{|c|c|c|c|c|c|}
\hline \multirow[b]{2}{*}{ Validator } & \multicolumn{4}{|c|}{ Aspects of Assessment } & \multirow{2}{*}{$\begin{array}{l}\text { Cate- } \\
\text { gory }\end{array}$} \\
\hline & Design & $\begin{array}{c}\text { Technic } \\
\text { al }\end{array}$ & Benefit & Total & \\
\hline expert 1 & 28 & 30 & 37 & 95 & Eligible \\
\hline expert 2 & 30 & 34 & 39 & 103 & $\begin{array}{l}\text { Sangat } \\
\text { Eligible }\end{array}$ \\
\hline Average & 29 & 32 & 38 & 99 & \\
\hline Category & Eligible & Eligible & Eligible & Eligible & \\
\hline Percentage & $81 \%$ & $80 \%$ & $79 \%$ & $80 \%$ & \\
\hline
\end{tabular}

The feasibility tests of the instructional media were obtained from 2 media experts. Assessment from the design aspect obtained $81 \%$, the technical aspect obtained $80 \%$, and the benefit aspect obtained $79 \%$. Total data were obtained from both experts got $80 \%$, in which it was included into the "Eligible" category. Seeing the results, the product of the learning media was "Eligible" to be used as an instructional media on the subjects of basic programming at vocational high school.

Furthermore, a limited trial of the product was conducted on 13 students of $\mathrm{X}$ class at Mechatronics Department in a vocational high school in Yogyakarta. The obtained data were results of the product assessment by students. The students assessed the product based on questionnaires. The development of the questionnaires based on the Learning Object Review Instrument (LORI) [10][11]. Totally it had 17 statements of question with 4 choices of answers. The statement on the questionnaire covered course material, learning and technical aspects.

According to Table 3, the percentage of feasibility test of such learning media product reached $83 \%$ in course material aspect, $85 \%$ on learning aspect and $81 \%$ on technical aspect. The total percentage of these 3 aspects earned $83 \%$. Thus it could be concluded that the learning media product was "very eligible" to be used as a learning media in vocational high school particularly for supporting Basic Programming subjects in class X of Mechatronics Department. 
TABLE III. THE RESULTS OF FEASIBILITY TEST BY STUDENTS

\begin{tabular}{|c|c|c|c|c|c|}
\hline \multirow[b]{2}{*}{ No } & \multirow[b]{2}{*}{ Name of Student } & \multicolumn{3}{|c|}{ Aspects of Assessment } & \multirow[b]{2}{*}{ Total } \\
\hline & & $\begin{array}{c}\text { Course } \\
\text { Material }\end{array}$ & Learning & $\begin{array}{l}\text { Techni- } \\
\text { cal }\end{array}$ & \\
\hline 1 & Herman Ismail P & 14 & 22 & 23 & 59 \\
\hline 2 & Candra Bangkit S & 14 & 20 & 21 & 55 \\
\hline 3 & Husain Kamal R & 13 & 19 & 21 & 53 \\
\hline 4 & Ilham ananda B & 13 & 23 & 23 & 59 \\
\hline 5 & $\begin{array}{l}\text { Hafidz } \\
\text { Firmansyah }\end{array}$ & 13 & 21 & 24 & 58 \\
\hline 6 & Arvian Rifky N & 12 & 21 & 25 & 58 \\
\hline 7 & Ekky Ramadhan & 16 & 18 & 22 & 56 \\
\hline 8 & Forel Fahinsa H.R & 12 & 19 & 19 & 50 \\
\hline 9 & Abi Prima Yudha & 12 & 20 & 22 & 54 \\
\hline 10 & $\begin{array}{l}\text { Alfian Dwi } \\
\text { Saputra }\end{array}$ & 12 & 18 & 21 & 51 \\
\hline 11 & $\begin{array}{l}\text { Bagus Dika } \\
\text { Ardianto }\end{array}$ & 14 & 18 & 24 & 56 \\
\hline 12 & Johan Bintang P & 13 & 23 & 25 & 61 \\
\hline 13 & Ichsan Maulana A & 15 & 23 & 25 & 63 \\
\hline \multicolumn{2}{|c|}{ Total Amount } & 173 & 265 & 295 & 733 \\
\hline \multicolumn{2}{|c|}{ Average } & 13,31 & 20,38 & 22,69 & 56,38 \\
\hline \multicolumn{2}{|c|}{ Category } & $\begin{array}{c}\text { Very } \\
\text { Eligible }\end{array}$ & $\begin{array}{c}\text { Very } \\
\text { Eligible }\end{array}$ & Eligible & $\begin{array}{c}\text { Very } \\
\text { Eligible }\end{array}$ \\
\hline \multicolumn{2}{|c|}{ Persentase $\%$} & $83 \%$ & $85 \%$ & $81 \%$ & $83 \%$ \\
\hline
\end{tabular}

\section{CONCLUSION}

The performance of the instructional media of the visual block programming for supporting teaching and learning of the basic programming subjects is in accordance with the purposes of design. This is indicated by each sensor module that can detect the change of a given stimulus; the proximity sensor can detect the change of distance of the existing object in front of it. The responses of the sensors are processed by the Arduino can be displayed on the main module i.e. the Raspberry Pi interface monitor.
The feasibility level of the product of instructional media according to the assessment of course material experts includes the category "Eligible". The feasibility level according to the assessment of the instructional media expert gets the category "Eligible". The feasibility level according to the assessment of students gets the category "Very Eligible". It means that the product is eligible to be used for supporting the teaching learning process of the Basic Programming class, particularly for Class $\mathrm{X}$ of Mechatronics Engineering department in vocational high school.

\section{REFERENCES}

[1] Lifelong Kindergarten. "Programming Scratch visual block in Raspberry Pi”. Diperoleh 27 juli 2017.http://d.umn.edu. 2013.

[2] Depdikbud. "Peraturan Pemerintah Republik Indonesia Nomor 32 tentang Standar Nasional Pendidikan Indonesia". Kementerian Pendidikan dan Kebudayaan Republik Indonesia. 2013.

[3] G. Lory. "Getting started with Raspberry Pi". Diperoleh 27 juli 2017. www.raspberrypi.org. 2017.

[4] Robotshop. "Arduino Mega 2560 Datasheet". http://www.robotshop.com/media/files/pdf/arduinomega2560datasheet.p df. Diperoleh 8 September 2017.

[5] J. Bruce."Profesional Visual Studio 2013". Canada: John Wiley \& Sons, Inc. 2014.

[6] Iswanto. "Belajar Mikrokontroler AT89S51 dengan bahasa C". Penerbit ANDI Yogyakarta. 2011.

[7] A. Kadir. "Panduan Praktis Mempelajari Aplikasi Mikrokontroler dan Pemrogramannya menggunakan Arduino". Penerbit ANDI Yogyakarta. 2013.

[8] B. Robert M. "Instructional Design: The ADDIE Approach". Springer, New York. 2009.

[9] A.Arsyad. "Media Pembelajaran (Edisi Revisi)". PT Rajagrafindo Persada. Jakarta. 2016

[10] F. Krauss, M. Ally. "A Study of the Design and Evaluation of a Learning Object and Implications for Content Development". Interdisciplinary Journal of Knowledge and Learning Objects Volume 1. 2005.

[11] Yavuz Akpinar."Validation of a Learning Object Review Instrument: Relationship between Ratings of Learning Objects and Actual Learning Outcomes". Interdisciplinary Journal of E-Learning and Learning Objects Volume 4. 2008. 